IZA DP No. 3636

\title{
The Effect of Prayer on God's Attitude
} Toward Mankind

\author{
J ames Heckman
}

August 2008 


\title{
The Effect of Prayer on God's Attitude Toward Mankind
}

\author{
James Heckman \\ University of Chicago, University College Dublin, \\ American Bar Foundation and IZA
}

Discussion Paper No. 3636

August 2008

(forthcoming in: Economic Inquiry)

\begin{abstract}
Any opinions expressed here are those of the author(s) and not those of IZA. Research published in this series may include views on policy, but the institute itself takes no institutional positions on policy, let alone religion.
\end{abstract}

IZA Discussion Papers often represent preliminary work and are circulated to encourage discussion and His divine favor. Citation of such a paper should account for its fallible character. It may also be predetermined that a revised version will be available from the author.

IZA

P.O. Box 7240

53072 Bonn

Germany

Phone: +49-228-3894-0

Fax: +49-228-3894-180

E-mail: iza@iza.org

The Institute for the Study of Labor (IZA) in Bonn is a local and virtual international research center and a place of communication between science, politics and business. IZA is an independent nonprofit organization supported by Deutsche Post World Net. The center is associated with the University of Bonn and offers a stimulating research environment through its international network, workshops and conferences, data service, project support, research visits and doctoral program. IZA engages in (i) original and internationally competitive research in all fields of labor economics, (ii) development of policy concepts, and (iii) dissemination of research results and concepts to the interested public. 
IZA Discussion Paper No. 3636

August 2008

\section{ABSTRACT}

\section{The Effect of Prayer on God's Attitude Toward Mankind}

This paper uses data available from the National Opinion Research Center's (NORC) survey on religious attitudes and powerful statistical methods to evaluate the effect of prayer on the attitude of God toward human beings.

JEL Classification: Z12

Keywords: $\quad$ kernel estimator, unobserved variables

Corresponding author:

James J. Heckman

Department of Economics

University of Chicago

1126 East 59th Street

Chicago, IL 60637

USA

E-mail: jjh@uchicago.edu

* The first draft of this paper circulated in July 1980. It evoked a response from Father Andrew Greeley, the noted Catholic priest and sociologist, which I attach. Ivan Werning made helpful comments on the current draft. 
This paper uses data available from the National Opinion Research Center's (NORC) survey on religious attitudes and powerful statistical methods to evaluate the effect of prayer on the attitude of God toward human beings.

The technique — due to Singh (1977) — is briefly described here. Let $Y$ be God's attitude arrayed on a scale ranging from zero to one. This is an unobserved variable. Let $X$ be the intensity of prayer in the population. It too is scaled between zero and one. The population density of prayer is summarized by a univariate density $f(X)$ which has been estimated by Father Greeley (1972).

Accept on faith that the conditional density of $X$ given $Y$ is of the form

$$
g(X \mid Y)=a(Y) \exp (X Y)
$$

where $a(Y)$ is an unknown, continuous, positive, and differentiable function. Singh demonstrates that under his conditions

$$
E(Y \mid X=x)=\frac{f^{\prime}(x)}{f(x)},
$$

where $f^{\prime}(x)$ is the derivative of $f(X)$ at $X=x$. Thus, from the population distribution of prayer, we can estimate the population regression function of God's attitude as a function of prayer. For a derivation, see Singh (1977).

\section{Empirical Application}

Greeley estimates that $f(X)$ is bimodal for $X$ scaled between zero and one. Many people almost never pray and many others pray a lot. Using Greeley's numbers, we reach the following important conclusions reported in Table 1, where " $t$ " statistics for the Parzen (1962) kernel estimator of $f(X)$ are presented in parentheses. See Figure 1, which graphs the estimated relationship at points of evaluation. 
Table 1:

\begin{tabular}{c|c|c|c}
\hline \hline & $E(Y \mid X=x)$ & $t$ statistic & standard error \\
\hline$x=0.0$ & 0.4 & $(3.2)$ & 0.1 \\
$x=0.2$ & -1.3 & $(4.6)$ & 0.3 \\
$x=0.4$ & -2.3 & $(6.7)$ & 0.3 \\
$x=0.6$ & -3.0 & $(9.3)$ & 0.3 \\
$x=0.8$ & 0.0 & $(2.1)$ & 0.0 \\
$x=1.0$ & 2.0 & $(1.8)$ & 1.1 \\
\hline
\end{tabular}

The empirical conclusion from this analysis is important. A little prayer does no good and may make things worse. Much prayer helps a lot.

\section{Discussion}

Using a powerful method due to Singh, we have established a relationship between God's attitude toward man and the amount of prayer transmitted to God. The method presented here is applicable to a number of important problems. Provided conditional density (1) is assumed, we do not need to observe a variable in order to compute its conditional expectation with respect to another variable whose density can be estimated. For example, one can extend current empirical work in a variety of areas of economics to estimate the effect of income on happiness or the effect of income inequality on democracy. We conjecture that this powerful method can be extended to the more general case when $X$ is not observed either. 


\section{References}

Greeley, A. M. (1972). Unsecular Man: The Persistence of Religion. New York: Schocken Books.

Parzen, E. (1962, September). On estimation of a probability density function and mode. Annals of Mathematical Statistics 33 (3), 1065-1076.

Singh, R. S. (1977). Applications of estimators of a density and its derivatives to certain statistical problems. Journal of the Royal Statistical Society. Series B (Methodological) 39 (3), 357-363. 
Figure 1:

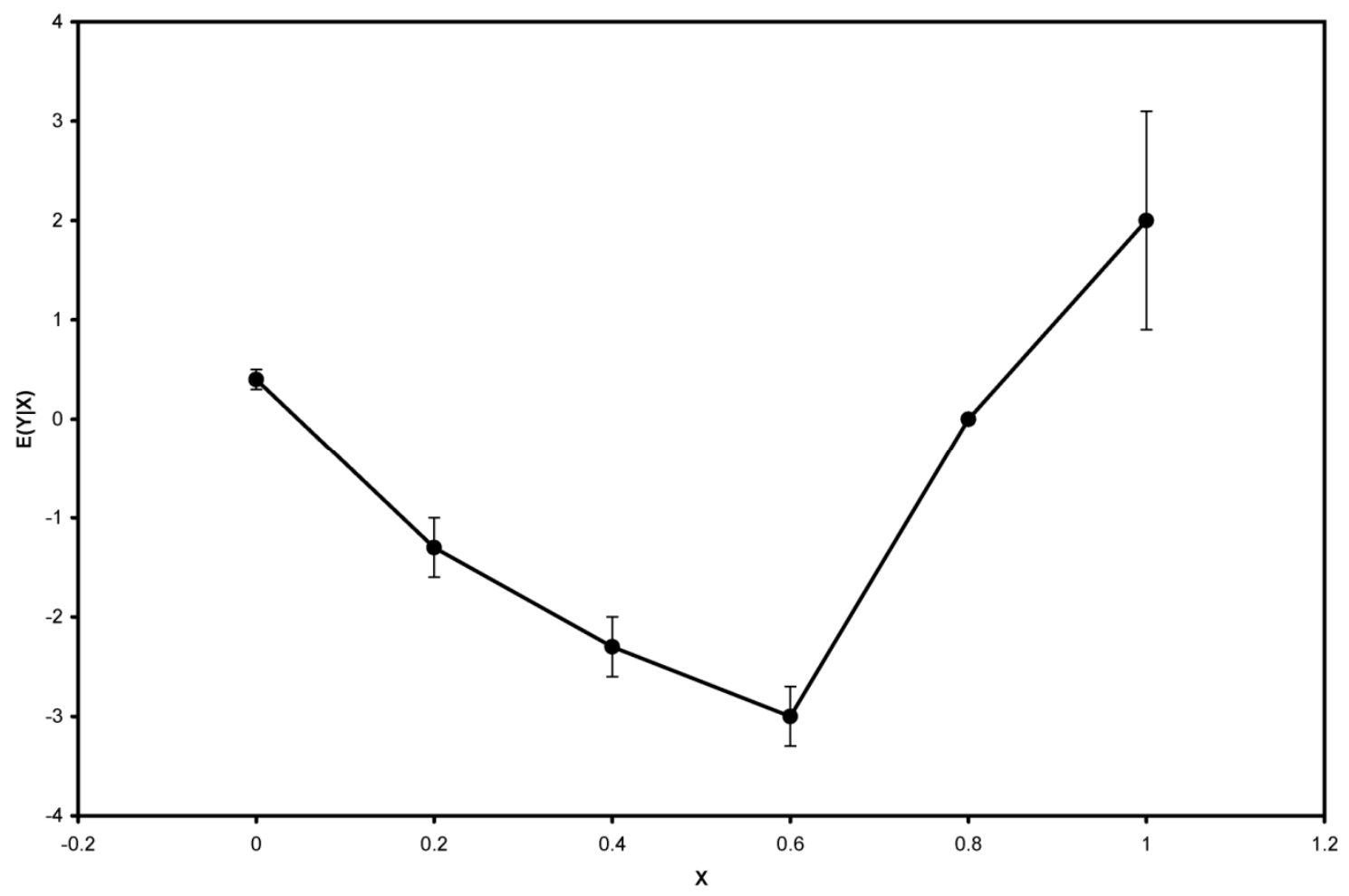




\section{Appendix from Father Andrew Greeley in Response to this Paper}

DATE October 10, 1983

TO James Heckman

FROM Andrew M. Greeley

SUBJECT

Richard Robb showed me your interesting essay about the effect of prayer on God's attitude. I envy you your ingenuity of economic models. Our survey interviewers have been trying to get an interview with God for a long time but the reaction, thus far, has always been that She was not home. Econometric models are much neater!

I'm enclosing a copy of a brief memo of mine about the persistence of prayer. My colleague, Phil Morgan, has developed some log linear models which show that prayer increases with age because, the older people are, the more likely they are to believe that prayer works. This may be wishful thinking, but the fact that it's wishful thinking doesn't necessarily mean that it's not true!

And the attitude that prayer works seems to be a life cycle rather than a generational or cohort effect.

The next thing to inquire about is whether the saints are listening!

AMG/jk

cc: Richard Robb 